\title{
Labor Disputes and Unemployment Compensation
}

\author{
LEONARD LESSER
}

THE unemployment compensation laws of all states include labor disputes as one of the reasons which may lead to disqualification. ${ }^{1}$ While the disqualification has been of relative unimportance during recent years this has been due to fewer labor disputes during the var period rather than to the limited scope of the disqualification itself.

\section{State Law Variations.}

Although the one factor common to all statutory prorisions is the existence of a labor dispute, ${ }^{2}$ most states do not disqualify all workers whose unemployment is caused by the labor dispute itself. Where, notwithstanding the labor dispute and its attendant circumstances, production is continuing or has been restored to its normal level, work: may no longer be available to the former workers at the establishment, and their unemployment may, therefore, be due primarily to lack of work. ${ }^{3}$ Consequently, more than one-half of the states require that before disqualification may be imposed the worker's unemployment must be due to a "stoppage of work which exists because of a labor dispute." 4

$\dagger$ Senior Attorney, Federal Security Agency.

1. A general discussion of the interpretation accorded to these provicions by toth ad. ministrative tribunals and courts is contained in Pribram, Compensation for Uncmployment during Industrial Disputes (1910) 51 MontalY L.1B. Rev. 1375; Fierst and Speetor, Uremployment Compensation in Labor Disputes (1940) 49 YaLE L. J. 461; Issues Inrolred in Decisions on Disputed Clainus for Unemployment Benefis, Sochul Securiry Yearroon: 1910 (1941) 31,64 .

2. The term labor dispute is defined in only one state unemployment compensation law, Alabama, Section 6B(a), 26 ALA. Code (1940) \$214(A), which incorporates the definition in the Norris-La-Guardia Act, 47 STaT. 73 (1932), 29 U.S.C. $\$ 113$ (1940). Definitions in anti-injunction, anti-picketing and labor relations legislation, while looked to for guidance, are generally not considered controlling in defining the term in the labor dispute disqualification in unemployment compensation laws. Dallas Fuel Co. v. Horne, 230 Iown 1148,300 N. W. 303 (1941); Miners v. His, 123 W. Va. 637, 17 S. E. (2d) 810 (1941). But cf. Ben. Ser. 4139-N. J. D (V3-S) and Ben. Ser. 4338-N. J. D (V3-9) in which the Board of Review held that it was bound by a decision of the court in Feller v. Local 144, I. L. G. W. U., 121 N. J. Eq. 452, 191 Atl. 111 (1937), a case which did not arise under the unemployment compensation law and which was thereafter overruled in Feller v. Local 144, I. L. G. W. U., 129 N. J. Eq. 421,19 A. (2d) 784 (1911). In some cases the definition found in the British Act is referred to. Ben. Ser. 2422-Va. R (V3-1).

3. While this would not hold true where the vacancies are merely filled temporarily pending determination of the dispute, it would be extremely difficult in many cases to determine whether vacancies are filled temporarily or permanently.

4. The introduction of the stoppage clause has also been explained on the ground that it tends to preserve the neutrality of the state in labor disputes. But sse page 000 injre. If benefits were paid to workers on strike while work at the establishment mas not baing done because of the dispute, it might be contended that the state was taling sides in the 
The interdependence of industry, however, may result in conditions whereby workers engaged in one stage or line of the economic process may be forced to suspend their work because of the existence of a dispute in another stage of the process. Thus, a strike of engineers on an important railroad system might easily affect the employment of hundreds of thousands of workers in almost every industry. Since most of the workers who are idle may in no sense be interested in the dispute, they are protected from disqualification by a clause in all state laws (save that of Pennsylvania) which imposes disqualification only if the labor dispute is at the establishment at which the worker was last employed. 5

Such provisions alone, however, would not exclude from disqualification all cases in which a causal relation between the worker's unemployment and the stoppage of work (or the labor dispute) exists and the worker is, nevertheless, not implicated in the dispute. Workers may be employed in an establishment affected by a labor dispute involving the terms and conditions of work of other groups of workers and may become unemployed because of an ensuing stoppage although they are not engaged in and have no stake in the dispute. Hence most state laws contain provisions designed to give relief from the disqualification to any claimant if it appears that as an individual he was not participating in, financing, or directly interested in the dispute, nor indirectly interested in the dispute through the interests or actions of a "grade or class" of which he is a member. 6 Although the "grade or class" provision has been criticized as sometimes resulting in the dis-

dispute by paying benefits to workers in recognition of their loss of wage income while doing nothing to diminish the loss to the employer because of the non-performance of work at his establishment.

The term "stoppage of work" is generally held to refer to the status at the plant rather than the status of the individual. Lawrence Baking Co. v. Unemployment Comp. Comm., 308 Mich. 198, 13 N. W. (2d) 260 (1944); Magner v. Kinney, 141 Neb. 122, 2 N. W. (2d) 689 (1942); In re Steelman, 219 N. C. 306, 13 S. E. (2d) 544 (1941). Contra: Board of Rev. v. Mid-Continent Petroleum Corp., 193 Okla. 36, 141 P. (2d) 69 (1943).

5. The simple phrase "at the establishment" is used only in a limited number of laws (Alabama, California, District of Columbia, Kentucky, Michigan, New Yorl;, Ohio, Rhode Island, and Wisconsin); the Utah law refers to a "factory or establishment"; the 40 other laws refer to a "factory, establishment or other premises."

The primary question in interpreting these phrases has been with respect to whether plants separated from other entities by considerable distances should be considered as a single establishment because they are managerially and functionally synchronized and in. terdependent. In Spielmann v. Industrial Comm., 236 Wis. 240, 295 N. W. 1 (1940), and Chrysler Corp. v. Smith, 297 Mich. 438, 298 N. W. 87 (1941), the court held that coordinated plants constituted a single establishment. The Illinois Supreme Court, however, relying strongly on the words "or other premises," held that units which are geographically separated constitute separate establishments. Walgreen Co. v. Murphy, 386 111. 32, 53 N. E. (2d) 390 (1944).

6. Only eight state laws (Alabama, California, Delaware, Kentucky, New York, Ohio, Pennsylvania, Wisconsin) contain no relief provision of this type. 
qualification of workers who are thrown out of work because of a labor dispute between an employer and a minority of the employees even though they disapprove of the actions of the workers who are parties to the dispute, a limitation of the disqualification to individuals who personally participate is subject to two objections. ${ }^{7}$ It would permit a stoppage of work to be embarked on by the withdrawal of a small number of pivotal men in the establishment in the knowledge that a majority of the workers will get benefits and thus augment the workers' fighting fund. On the other hand, it permits the unemployment compensation system to be used to induce defections from a union which calls a strike by the promise of benefits to workers who take no part in the dispute.

Despite limiting provisions of these linds, few state laws qualify in any way the type of dispute which may lead to disqualification. Though a labor dispute and stoppage of work may result from the employer's unwillingness to furnish work except under changed terms or conditions which the workers are unwilling to accept, ${ }^{8}$ most state laws would not preclude disqualification. Nor under most state laws are the merits of the dispute important. ${ }^{10}$ It is irrelevant that the employer

7. A general discussion of the objections to and the purposes of the "grade or class"

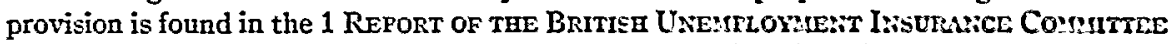
(1927) 65 . The purposes of the provision, however, are largely nullified in thoze states in which it is interpreted to refer to a group of workers suberribing to common views, policies, or demands, Ben. Ser. 1S45-Ind. A (V2-S), or to a group of vorkers whose duties are so interrelated as to make the work of one dependent on the work of the other, Ben. Sar. 2117-210. A (V3-1). But of. Members of Iron Workers' Union of Provo v. Intustrial Comm., 10 s Utah 242,139 P. (2d) 208 (1943), in which it was held that the term refers to a group of workers as determined by the terms or conditions under which they worls or by the i:sues involved in the dispute.

8. A labor dispute under such circumstances, i.e., a denial of worl opportunity unles 3 the workers submit to the employer's terms, is in effect a lockout. Sae page $173 \mathrm{infra.}$

9. The only states that expressly exclude loclouts from the concept of labor disputes are Arkansas and Kentucly. Lockouts are, however, excluded by implication by the lawis of California, Colorado, Pennsylvania, Ohio, Utah, and West Virginia. The Colorado, Ohio, and Utah laws refer to "strikes." In Bodinson Mifs. Co. v. Employment Comm., $17 \mathrm{Cal}$. (2d) 321, 109 P. (2d) 935 (1911), Section 56(a) of the California law [3 Car. Gri. L.ivs (Deering, 1911) Act \$780d, \$56(a)] was interpreted to apply only to individuals who "voluntarily leave their work because of a trade dispute." The Fennsylvania law has also tsen construed to require voluntary action on the part of the claimant. See Philligs v. Unemployment Comp. Bd. of Rev., 152 Pa. Super. 75, 30 A. (2d) 718 (1943); Bonner v. Uneraployment Comp. Bd. of Rev., 156 Pa. Super. 367, 40 A. (2d) 106 (1944). In Homer Laughilin China Co. v. Board of Rev., W. Va. C. C., Kanawha Cy., 1944, CCH Unemployment Ins. Serv.-W. Va. I 8058 (affirming on rehearing an earlier unpubliched opinion), a proviso to the West Virginia provision which precluded application of the labor dispute disqualification if "an employer shuts down an operator or dismisses his employees in order to force wage reduction, changes in hours, or worling. conditions" was beld applicable where the employer refused to permit men who had engaged in an illegal strile to return to vorls except as new employees.

10. Johnson v. Pratt, 200 S. C. 315,20 S. E. (2d) $\$ 65$ (1942); Board of Rev. v. Mid- 
may have acted unreasonably or contrary to the terms of an agreement or long-established custom. ${ }^{11}$ The fact that a dispute may be occasioned by a breach of law by the employer is immaterial. ${ }^{12}$ Even though the dispute is caused by the insistence of the employer upon conditions of work which are less favorable than those prevailing in the locality or which are otherwise specified in the unemployment compensation law itself as rendering any work unsuitable, the labor disqualification is applicable. Yet workers who refuse to accept or who left a job where such conditions of work exist are protected from disqualification. ${ }^{13}$ To pay benefits to workers who have never had or have severed a connection with the employer while denying benefits to those workers who are most likely to be subjected to the illegal or substandard conditions seems anomalous. Yet, under present statutory provisions, state unemployment compensation laws deny benefits to workers who are otherwise eligible merely because they are seeking to maintain rights accorded to them by the broad pattern of labor legislation of which the unemployment compensation laws are but one part.

Recognition of these anomalies has led the British Umpire and a few state tribunals to modify the general rule that the merits of the dispute are immaterial by holding that, if the employer is willing to continue claimant in employment only on terms which if accepted would make the claimants participants in an illegal act or render the contract void though not illegal, the legislature could not have intended the disqualification to apply. ${ }^{14}$ Such decisions are, however, too infrequent, and the principles enunciated therein have not been extended to exclude from disqualification situations in which the claimants would not be

Continent Petroleum Corp., 193 Okla. 36, 141 P. (2d) 69 (1943); Ben. Ser. 1847-Mass. R (V2-8); Ben. Ser. 5950-Ohio R (V4-6).

The laws of Arizona, Arkansas, Montana, and Utah specifically provide that the disqualification is inapplicable if the labor dispute is caused by the employer's failure to conform to a law of the State or United States pertaining to hours, wages, or other conditions of work. Arkansas and Montana also protect workers where the employer fails or refuses to conform to the provisions of any law of the state or United States pertaining to collective bargaining. Arkansas also extends relief if the employees are protesting wages, hours, or working conditions which are not desired by the majority of the employees. West Virginin precludes disqualification if the employees are required to accept wages, hours, or other conditions of work less favorable than those prevailing in the locality or denied the right to collective bargaining under generally prevailing conditions.

11. Ben. Ser. 1968-Conn. R (V2-9); Ben. Ser. 4151-Wash. A (V3-8).

12. See Ben. Ser. 5535-Fla. A (V4-4).

13. Ben. Ser. 3860-Mo. A (V3-7).

14. Brit. Ump. 4635/36; Brit. Ump., 6138/36; Brit. Ump. 2358; see Ben. Ser. 1430R. I. D (V2-5) in which it was held that claimants who left work because of the employer's violation of a collective agreement fixing wages were not unemployed because of a trade dispute when the new piece rate set by the employer would not enable claimants to earn the minimum wages established by the State Director of Labor. See also Ben. Ser. 3113-Ala. $\mathrm{R}(\mathrm{V} 3-4)$. 
participants in an illegal act, or the contract void in law, but in which they are nevertheless being denied rights accorded to them by the legislature, or in which the issue turns on the violation of a legal contract. Statutory amendment would seem to afford the only real solution.

\section{Arguments Used to Support Broad Disqualification.}

The reasons commonly offered in support of the existing broad disqualification do not, upon close analysis, seem persuasive.

1. "Voluntary" Character of Untemployment. It is first argued that the purpose of unemployment insurance is to protect the worker against involuntary unemployment, that when men go out on strike they are not unemployed against their will and must be disqualified. ${ }^{15}$ But, whatever may be said of a strike by employees who are relatively well circumstanced and who are merely seeking to better their conditions still further, a broad classification of all strikes as "voluntary" is reminiscent of the decision of the United States Supreme Court striling down a minimum wage law for women on the ground that the law impaired the liberty of contract of the women affected. ${ }^{16}$ The voluntary character of a strike which is caused by the attempt of the employer to impose substandard, illegal or other unreasonable conditions of work on his employees is doubtful. If the "voluntary" nature of an individual's unemployment is to be the test, there would seem to be as much reason to consider the economic and psychological pressures which may be present in the case of a concerted leaving of work as in the case of an individual leaving. ${ }^{17}$

Even if all strikes are considered "voluntary," it does not follow that the unemployment resulting therefrom should not be compensated. The fact that benefits are paid to individuals who voluntarily leave work but with good cause or who refuse an offer of unsuitable employment indicates that the criterion of voluntariness is subordinated to other criteria which from the social point of view are considered paramount. If it is socially desirable to pay benefits to workers who have left unsuitable employment or refuse to accept such employment, there seems to be no good social reason, so far as the question of voluntary unemployment is concerned, for denying benefits to workers on strike because of conditions which make the work unsuitable. Nor does the test of involuntary unemployment explain the denial of benefits to

15. Douglas, Standands of Unemployarent Insuraice (1933) 59; Calce, Uzeyployarent Compensation Disqualificitions (1945) 21.

16. Adkins v. Children's Hospital, 261 U.S. 525 (1923), overruled in West Coast Hotel Co. v. Parrish, 300 U. S. 379 (1937).

17. For a discussion as to the circumstances when an individual's leaving worls will not be "voluntary" under the voluntary leaving disqualification see Kempfer, Disqusalifications or Voluntary Leaving and Mrisconduct, page 147 supra, at 155. 
persons not themselves on strike but who are members of the same grade or class of workers who are participating in or directly interested in the dispute.

Moreover, if the concept of involuntary unemployment is the basic reason for the denial of benefits in cases of labor disputes, it would seem clear that benefits should be paid to workers who are unemployed because of a lockout. Recognizing the "apparent logic" of such position it is, however, argued that there is no such sharp distinction between a "strike" and "lockout" as their formal definitions would lead one to believe; that since many strikes or lockouts occur merely because of an attempt by the employers or workers to preserve the "psychic value of attack by getting there first," it would be as difficult for an administrative body to determine which of the parties actually took the aggressive as to determine who is guilty of a defensive or offensive war. From this it is concluded that the most sensible policy is to refuse to pay benefits to workers who are thrown out of work because of either strikes or lockouts. ${ }^{18}$

Acceptance of the premise that because of the difficulty in distinguishing between a strike and lockout we must treat all workers unemployed as a result of any labor dispute in the same fashion does not, however, force one to accept the conclusion that disqualification should apply. It seems as reasonable, when considering legislation designed to benefit workers, to argue that since the purpose of unemployment compensation is to compensate workers who are involuntarily unemployed, workers who are locked out are clearly entitled to benefits, and that in view of the difficulty in distinguishing between a lockout and a strike benefits should be paid to all workers thrown out of work whether because of lockouts or strikes.

Nor is the conclusion that it is hardly possible to distingtiish between strikes and lockouts necessary. It may be true that a formal distinction between a strike and a lockout based on whether the employer refuses to furnish work or the employees refuse to work may result in unrealistic determinations, and that a determination based on whether the "strike" or "lockout" is called in order "to get there first" may be difficult to make. But whether or not the employer is the "aggressor" need not be based on formal distinctions or on whether the employer or the employees are merely trying to "get there first." An employer desiring to exert pressure upon his workers to submit to a change of terms or conditions of work need not resort to an actual shutting of the gates except in those rare cases in which he demands the doing of some affirmative act on the part of the employees, something beyond mere acquiescence in changed terms or conditions of work. Ordinarily, all

18. Douglas, Standards of Unearlotarent Insurance (1933) 60-1; Chace, UNEMIPLOYMENT COMPENSATION DisQUalifications (1945) 21. 
he needs to do is to make an announcement to his employees collectively, not as a bargaining offer but as an ultimatum, putting before them the alternative of reporting for work under the new terms or conditions or not coming to work at all. Where this is done, not in the ordinary process of exercising the employer's right to hire or discharge workers but in order to bring pressure upon the workers to submit to his demand, it would seem that such an ultimatum when followed by collective resistance might be considered for the purpose of an unemployment compensation law to involve a lockout rather than a strike regardless of who gets there first. This would seem to be especially clear where the employer has been dealing with his workers on a collective basis, particularly where there is in existence a collective agreement fixing the terms or conditions of work.

A distinction based on whether the employer or the workers are seeking to change the terms or conditions of work would not be difficult to make. Similar findings are frequently required in connection with determinations as to whether there is a leaving or refusal of work ${ }^{10}$ and the existence of good cause. Such a distinction would, moreover, in assessing responsibility for unemployment according to whether the employer or the employees is the aggressor in seeking to change the status quo, establish a more harmonious pattern under the statutory provisions. Thus, under the voluntary leaving provision, disqualification would be imposed where the claimant voluntarily talkes the initiztive in severing the employment relationship and is responsible for ensuing unemployment; under the labor dispute provision, disqualification would be imposed where claimants seek to enforce a change in the status quo by collectively ceasing work and thus are responsible for their unemployment, while disqualification would not be imposed where the claimants cease work in resistance to the employer's attempt to change the status quo through an ultimatum and the employer is thus responsible for their unemployment. Such a distinction would also be in accord with the trend in governmental policy to encourage the settlement of disputes by collective bargaining since the responsibility for the ensuing unemployment of the workers would not be on the employer if, instead of delivering an ultimatum, he is willing to negotiate while the workers continue to work upon the former terms pending the outcome of the negotiations.

Pointing in this direction are cases which, in defining a strike, place primary emphasis on whether the cessation of work results from an effort by employees to obtain more desirable terms. ${ }^{23}$ In a decision by

19. See Kempfer, Disqualifications for Voluntary Lcaring and arosconduct, page 147 supra.

20. Unemployment compensation decisions adopting this definition usually cite Iron Moulders' Union v. Allis-Chalmers Co., 166 Fed. 45, 52 (C. C. A. 7th 1908) (concurring opinion); Magner v. Kinney, 141 Neb. 122, 2 N. W. (2d) 689 (1942); Sandoval v. Industrial 
the Kentucky Court of Appeals arising out of the bituminous coal stoppage of 1939, the court stated that

“. . . it is not difficult to conceive of terms so onerous that their rejection by the employee would not be inconsistent with his right to receive unemployment compensation. Insistence on onerous terms by an employer, accompanied by a threat of dismissal if not accepted, might, under certain circumstances, constitute a 'lockout." "21

While the distinction made by the court closely approaches the view here suggested, it would seem irrelevant whether the terms offered by the employer are "onerous" so long as the change is sufficiently substantial to be the cause of the cessation of work by the employees.

2. "Strike and Lockout Benefits" Argument. It is further claimed that, since unemployment compensation is designed for the purpose of aiding workers "against the impersonal forces of cyclical, seasonal, technological, and casual unemployment," it would "not seem any part of the function of the state" to provide strike and lockout benefits out of unemployment compensation funds. ${ }^{22}$ But the payment of unemployment compensation is not limited to the payment of unemployment caused by these impersonal factors. It is generally agreed that benefits should not be denied to individuals who have left employment voluntarily for good cause, refused an offer of unsuitable employment, or been discharged for reasons other than misconduct, despite the fact that their unemployment or continued unemployment is not necessarily due to cyclical, seasonal, or technological causes.

Moreover, to call the payment of benefits to workers out of employment because of a labor dispute "strike or lockout benefits" is inappropriate as well as misleading. Strike or lockout benefits are paid to workers because they are on strike or are locked out to enable them to carry on successfully their strike with the employer. The payment of unemployment compensation in the circumstances, however, would be because of the unemployment of the individuals rather than because of their involvement in a labor dispute. That the effect of such payments may be similar does not make them strike or lockout benefits. The issue is not whether the state shall pay strike or lockout benefits but whether the unemployment of the individuals involved in a labor dispute is properly compensable. ${ }^{23}$

Comm., 110 Colo. 108, 130 P. (2d) 930 (1942); see also Barfield v. Standard Oil Co. of N. J., 172 Misc. 95, 103, 14 N. Y.S. (2d) 627, 634 (Mun. Ct., 1st Dist., 1939); Simon v. Schwachman, 301 Mass. 573, 576, 18 N. E. (2d) 1, 3, 4 (1938); Restatenent, TorTs (1939) \$ 797.

21. Barnes v. Hall, $285 \mathrm{Ky} .160,178,146 \mathrm{~S}$. W. (2d) 929,937 (1940), cerl. denied, 314 U. S. 628 (1941).

22. Douglas, Standards of Unemployment Insurance (1933) 61. See also Cihace, UNEMrLoynent CoMpensation DisQUalifications (1945) 21.

23. In this connection it may be observed that relief funds are paid to persons who are 
It is argued, however, that under our political system the State should be neutral in industrial conflicts, that the payment of benefits under such circumstances would amount to subsidizing the position of the workers in a labor dispute. ${ }^{24}$

Even accepting the thesis that unemployment compensation systems should be neutral in labor disputes, it by no means follows that benefits should be denied. To the extent that payment of benefits would have the unneutral effect of supporting workers and fostering strikes, the denial of benefits would have the unneutral effect of supporting employers and discouraging strikes and fostering lockouts. Nor does the fact that workers denied benefits are no worse off than if the unemployment compensation law had never been passed alter the effect of the denial of benefits. The very existence of the law with the promise of benefits to those who do not in concert with other workers refrain from working amounts to considerable pressure to deter workers from combining their economic strength. This is particularly true if union membership or the payment of union dues is construed to amount to participation in,$^{25}$ or financing of, ${ }^{25}$ the dispute. Moreover, under sy'stems in which the denial of benefits to large numbers of persons has an immediate effect on the rate of contributions which an employer is required to pay, ${ }^{27}$ it is questionable whether neutrality is effected by the denial of benefits. An employer, who knows that because of slackness of trade or for other reason he may be forced to close his business or lay off a certain class of workers may by the disqualification be encouraged to precipitate a dispute.

More basically, however, objection may be made to the concept of neutrality here urged. While it may be proper for a state to be "classless" in the sense of refraining from acting as the agent or ally of a particular class, it does not follow that it should refrain from acting for the common good even though the immediate effect is the benefit or protection of a particular group. Intervention by federal and state

in need without regard to the fact that need was due to their being on strilse. Sce SE:. Des. No. 56, 74th Cong., 1st Sess. (1935) 653; 1 Aвbotr, Public Assista:ice (1940) 382, 443; Schindler, Collectize Bargaining and Unemploymenl Insurance Logislalion (1938) 38 Cot. L. Rev. 858, 873. See also City of Spring Valley v. County of Bureau, 115 Ill. App. 545, 549 (1904) (holding a county rule withholding relief from strikers "both unreaconable and void").

24. Douglas, Standards of Uneuployment Insurance (1933) 61; Cunce, Uzesplovarent CoMpensation Disqualifications (1945) 21.

25. Ben. Ser. 3380-W. Va. R (V3-5); Ben. Ser. 1845-Ind. A (V2-8); Ben. Ser. 2410Fla. A (V3-1).

26. Ben. Ser. 2422-Va. R (V3-1); Ben. Ser. 6740-Wyo. A (V4-12), affirmed in Employment Security Commission of Wyoming, C-7-41 (unpublished).

27. Of the 45 laws which include provision for varying an employer's rate of contribution in accordance with his "experience," New York is the only state in which the payment or denial of benefits will have no effect on the employer's rate of contribution. For a discussion of the effect of experience rating on the payment of benefits ese Simrell, EmployurFault v. General Welfare as the Basis of Unemployment Compensation, 181 infra. 
governments in the economic life of their people is as old as the nation. itself. ${ }^{28}$ Examples of government "unneutrality" with respect to disputes between labor and capital are to be found in factory, safety and sanitation laws, laws for the establishment of minimum wages and maximum hours of work, workmen's compensation laws, and laws safeguarding the rights of workers to organize and bargain collectively through representatives of their own choosing. ${ }^{29}$ For the unemployment compensation system to ignore the fact that interests of different classes do sometimes conflict, and that inequities in the treatment of one group by another may require action by the state in the interest of all, is to return to an outmoded concept of laissez faire. ${ }^{30}$

Moreover, whatever may be the merits of this theoretical argument, it seems absurd to assert that a policy of "neutrality," i.e., denial of benefits, is called for in instances in which the dispute has been engendered by a breach of law by the employer or by worker-resistance to conditions which the unemployment compensation law itself has declared to be unsuitable. Since advantage to either the employer or his workers will result from the denial or payment of benefits, a more proper function of the state would be achieved by a determination made in the light of objective social policy and without regard to the existence of a dispute.

3. Fear of Actuarial Unsoundness. Lastly, it has been argued that since existing data on the frequency, distribution and duration of labor disputes would not provide an adequate basis for calculating the probable incidence of this risk, unemployment caused by labor disputes cannot with actuarial safety be included among the risks covered by unemployment compensation laws. ${ }^{31}$ Even if the line as to where disqualifications are to be fixed is based on mathematical determinations, it is somewhat ironical to contend that since protection against the

28. See, e.g., Witte, The Governaent in Labor Disputes (1932); Twentieti CenTURY FUND, LABOR AND THE GOVERNaIENT (1935) c. 7.

29. Numerous examples of both federal and state intervention are collected in Schindlor, Collective Bargaining and Unemployment Insurance Legislation (1938) 38 CoL. L. REv. 858, 869, n. 22.

30. An additional argument offered in support of the labor dispute disqualification is that it would be unfair to subsidize strikers by funds accumulated through employer contributions. See Ben. Ser. 2243-Mich. A (V2-12); Pribram, Compensation for Uncmployment during Industrial Disputes (1940) 51 Monthly LAB. Rev. 1375, 1376. But public policy should control the disqualification provisions regardless of the source of the funds. See Simrell, Employer-Fault vs. General Welfare as the Basis of Unemployment Compensation, page 181 infra. Moreover, it is now generally recognized that even though legally the incidence of such contributions falls on the employer, the real economic burden is passed on to the consumer or shifted back to the worker himself. See Yoder, Some Economic Implications of Unemployment Insurance (1931) 45 Q. J. EcoN. 622, 635; Brown, The Incidence of Compulsory Insurance of Workmen (1922) $30 \mathrm{~J}$. PoL. EcoN. 67, 76.

31. Pribram, Compensation for Unemployment during Industrial Disputes (1940) 51 Monthey LaB. REv. 1375, 1376. 
consequence of unemployment-the achievement of the purpose of an unemployment compensation law-will be hazardous or expensive, that such protection should be withheld for that reason alone. In any event, it does not appear that any of the present limitations on the disqualification, either as to the duration of or type of the disqualifying dispute, have proved actuarially unsound.

\section{Objections to Deletion of Disqualification.}

In the light of the basic objections to the broad statutory disqualification and the fictitious nature of the reasons offered in support thereof, it is not surprising that the deletion of the labor dispute disqualification from the statute and the application of the ordinary tests of disqualification for voluntary leaving without good cause, refusal of suitable work, etc., to workers involved in a labor dispute have been urged.32 While such arguments may be logically persuasive, there are, however, certain considerations against the application of the ordinary disqualifications to situations involving labor disputes and for some special statutory treatment of such cases.

Unemployment caused by a strike or a lockout is merely the result of the use of a cessation of work or of the furnishing of work as an instrument to force the other party to accede to certain demands. Unlilie the unemployment resulting from a discharge or voluntary leaving, there is no final severance of the employer-employee relationship. ${ }^{33}$ Accordingly, if unemployment caused by a labor dispute were to be covered by the voluntary leaving and discharge for misconduct disqualifications, it would require that a "leaving" and a "discharge" be construed to include temporary absences from work. Such a construction would seem to be unsound. ${ }^{34}$

Moreover, application of the voluntary-leaving disqualification would necessitate a determination by the unemployment compensation agency as to whether or not the unemployment of each individual out of work because of a labor dispute is voluntary. The issues involved and the difficulties inherent in determining whether any "leaving" is voluntary have been pointed out elsewhere in this issue. ${ }^{35}$ A determination as to whether each worker involved in a labor dispute is unem-

32. Fierst and Spector, Unemployment Compensation in Lator Dispules (1910) 49 Yale L. J. 461; Schindler, Collective Bargaining and Unumplogment Insurenec Legislation (1938) 38 CoL. L. REv. 858.

33. Thus under Section 2(3) of the National Labor Relations Act the term employee includes "any individual whose work has ceased as a consequence of, or in conncetion with, any current labor dispute. . . ." 49 ST.1T. 450 (1935), 29 U. S. C. $\$ 152(3)$ (1910).

34. See Kempfer, Disqualifications for Voluntary Lrasing and AFistondust, page 147 suspra, at 154 .

35. Ibid. See also Harrison, Statutory Purpose ard "Irsolantary Uncmplognenh," page 117 supra. 
ployed because of his own will, or the extent to which the economic, psychological factors commonly present in labor disputes may have deprived him of any free choice, would be impossible. Further, a disqualification which applies only to individual workers who voluntarily participate in the labor dispute would seem objectionable from the point of view of organized labor since the promise of benefits to those who do not participate in the strike is an inducement to defections from and division in the ranks of labor. ${ }^{36}$

A more basic objection to the application of the voluntary-leaving disqualification might be that it would require the unemployment compensation agency and the courts to determine both the justice of the parties' cause and the reasonableness of the strike or lockout as a means of enforcing their demands. While there would be no direct enforcement of the decision, an adverse decision might seriously prejudice the position and affect the chance of success of either party to the dispute. In effect, the disqualification for voluntary leaving as applied to labor disputes might closely approach a system of compulsory arbitration and, therefore, would be objectionable from the point of view of both organized labor and employers. ${ }^{37}$ Since an unemployment compensation scheme must enjoy public confidence to operate successfully, it might be disastrous to allow such agencies to adjudicate the issues in labor disputes to the extent of making a subjective determination as to which party is in the right.

\section{Objection to Narrowing the Definition of "Labor Dispute."}

Any attempt to remove the objections to the broad disqualification provision by administrative or judicial narrowing of the definition of "labor dispute" is subject to a serious danger. The term is also used in a provision found in all unemployment compensation laws precluding the disqualification of individuals who refuse new work vacant due directly to a labor dispute. ${ }^{38}$ While, in view of the differences in purpose and context, there would be no inconsistency between interpreting the term differently as between the labor dispute and suitable work disqualifications, ${ }^{39}$ there is always the danger that the differences in purpose will be overlooked and the same narrow definition of the term applied to those provisions where adequate protection can only be obtained through use of a broad definition. This would seem particularly

36. See page 169 supra. See also Human Aspects of the Transition from War to Pcace (1945) 5 LAwYers GUILd REv. 22, 31.

37. See Twentieth Century Fund, Labor and the Governaent (1935) 116.

38. Such provisions were enacted in all state laws to conform to the requirements of Section 1603(a)(5) of the Internal Revenue Code. See Menard, Refusal of Stitlable Work, page 134 supra.

39. See Fierst and Spector, Unemployment Compensation in Labor Disputes (1940) 49 YALE L. J. 461, 474-5. 
true where the two provisions employing the term appear in the same statute and must be interpreted by the same agency. Express statutory amendment which would precisely define the situations in which a disqualification is to apply would, therefore, seem to be required.

\section{Proposed Statutory Amendment.}

While it might be undesirable to have no labor dispute disqualification at all or to limit its application by a narrower definition of "labor dispute," the same objections would not seem applicable to a statutory exception to the disqualification where specific facts legislatively determined as "just cause" exist. A finding by an unemployment compensation tribunal that the "labor standards" mentioned in the unemployment compensation statute are not involved in the dispute and, therefore, that benefits must be denied would not amount to a finding that the strike is nevertheless without cause and, hence, would not be likely to prejudice the strikers in public opinion. Under other disqualification provisions of the state unemployment compensation law the agency will in any event be called upon to determine whether an offer of work involves substandard conditions or whether a claimant would have to join a company union or be required to refrain from joining, or to resign from a bona fide labor organization. Similarly, in determining whether or not there is "good cause" for a leaving or refusal of work, it would seem necessary that it determine whether the wages or the conditions of work offered violate the standards set forth in any other statute. 41 The fact that a labor dispute may be present would not make such determination more difficult.

It is true that if the labor dispute disqualification were further amended to exclude disputes arising because of practices of the employer which violate other state or federal laws, such as labor relations acts, more difficult administrative problems would be presented. Agencies have been set up to administer such acts and to determine when they have been violated. To place upon the unemployment compensation agency the responsibility of making a similar determination, particularly in view of the difficult nature of such questions, might result in unseemly conflicts between its determinations and those of the agency charged with the administration of such law. However, there is the possibility of conflict with decisions of another tribunal under existing statutory provisions. ${ }^{12}$ As already indicated, questions as to

40. Menard, Refusal of Suitable Work, page 134 supra, at 139.

41. Ibid. See also Kempfer, Disqualifications for Volunlary Leaving and Misconduct, page 147 supra, at 159.

42. Compare Members of Iron Workers' Union of Provo v. Industrial Comm., 104 Utah 242, 139 P. (2d) 208 (19.13), in which it was held that the findings of a National Lator Relations Board trial examiner were not binding in determining whether the labor dispute was due to the failure of the employer to conform to a law of the United States pertaining to "hours, wages, or other conditions of work." 
whether the employer is violating a law the administration of which is the duty of another agency may arise in determining whether claimant should be disqualified for leaving work. Similarly, in determining whether claimant has been discharged for misconduct connected with the work, the unemployment compensation agency may be called on to determine whether he committed an act which may also be the basis for a criminal prosecution. ${ }^{43}$

While such conflicts could be avoided by a procedure which would suspend the determination as to whether benefits should be paid until the labor relations or other agency has made a determination as to whether or not the law has been violated, such procedure would probably result in delays in the payment of benefits of such length as to fail to carry out the primary purpose of unemployment compensation in meeting current needs. Even delays, however, would be preferable to a more speedy decision denying benefits in all cases.

An alternative procedure which would avoid the effects of conflicting decisions and still assure the prompt payment of benefits would be for the unemployment compensation agency to pay benefits in all cases where charges that the employer is violating a labor relations or other law have been filed with the agency charged with the administration of such law. If it is finally determined that there has been a violation of law, the amount of benefits might be deducted from any back pay awarded by such agency and turned over to the unemployment compensation agency to be deposited in the unemployment compensation fund. If no violation of law is found, the worker, as in other cases where an error in payment is discovered, could be required to repay the benefits received. ${ }^{44}$ Such a procedure would, of course, be possible only to the extent that the Labor Relations Board has the authority, and is willing, ${ }^{45}$ to issue an award ordering that an amount equal to the unemployment compensation benefits be deducted from the sum awarded the employee and paid over to the State unemployment fund.

43. Ibid. Determinations by the unemployment compensation agency would, of course, not be binding on the agency charged with the administration of such other law.

44. Such result is now current in states where "back pay" awards are considered to be wages, In re Skutnick, 268 App. Div. 1357, 51 N. Y. S. (2d) 711 (3d Dep't 1944), or in which a specific disqualification exists, ConN. GeN. Stat. (Supp. 1939) §1339e(b)(4)(A), as amended by Gen. Stat. (Supp. 1941) $§ 718 f(b)(4)(A) ; 10$ Ind. Stat. Ann. (Burns, Supp. 1943) $\$ 52-1507$ (f)(4).

45. The reluctance of the National Labor Relations Board to order deductions on account of unemployment compensation benefits is clear. Matter of Pennsylvania Furnace and Iron Co., 13 NLRB 49, 55 (1939). In Marshall Field v. NLRB, 318 U. S. 253 (1943), reh'g denied, 318 U. S. 802 (1943), it was held that unemployment compensation benefits were not "earnings" within the meaning of an order of the Labor Board requiring the employer to pay to the employees what they normally would have earned less "net earnings" during the prescribed period. Even should it desire to reverse its position, amendment of the National Labor Relations Act may be necessary in view of the decision of the Supreme Court in Republic Steel Corp. v. NLRB, 311 U. S. 7 (1940). 